\title{
Clay Soil Modification Techniques for the Adsorption of Heavy Metals in Aqueous Medium: A Review
}

\author{
Adekeye Damilola Kayode ${ }^{1 *}$, Asaolu Samuel Sunday ${ }^{2}$, Adefemi Samuel Oluyemi ${ }^{3}$, Adebawore \\ Adefusisoye Adegalu ${ }^{4}$, Osundare Olusegun Samson ${ }^{5}$, Ibigbami Olayinka Abidemi ${ }^{6}$, Olumide \\ Abisola Hellen ${ }^{7}$ \\ ${ }^{1-6}$ Department of Chemistry, Ekiti State University, Ado-Ekiti, Nigeria \\ ${ }^{7}$ Department of Geology, Ekiti State University, Ado-Ekiti, Nigeria
}

\begin{abstract}
*Corresponding Author: Adekeye Damilola Kayode, Department of Chemistry, Ekiti State University, Ado-Ekiti, Nigeria
\end{abstract}

\begin{abstract}
Clay modification techniques have been employed to improve heavy metals adsorption properties of clay minerals for removal of the metals from their respective aqueous solutions. These modification techniques enhance the surface area, pore volume, and number of present active sites on the surface of the clay. In this study, recently developed and newly applicable techniques such as chemical, physical (thermal), biogenic and mechano-chemical treatments are reviewed and discussed as treatment techniques for modifying clay minerals. Intercalation and pillaring of clay minerals are chemical processes through which modification could be achieved. Surface doping and chemical grafting of polymer onto clay could produce superadsorbent materials with highly enhanced adsorption properties. Also, activation, structural transformation and disruption of clays could be achieved by thermal treatment. Eco-friendly mechanochemical method which eliminates the use of solvents is also used to achieve chemical processing and transformation of clay for adsorption purpose while biogenic modification which involves the fortification of clay with organic biomass and composites is a promising technique for modification and enhancement of clay for heavy metals adsorption. The adsorption properties of different modified clay minerals are also discussed in comparison with their raw (unmodified) form.
\end{abstract}

Keywords: modification; techniques; physical; chemical; mechano-chemical; biogenic; polymer

\section{INTRODUCTION}

Variety of clays and clay minerals play an important role in the environment and used as an effective adsorbent material for the removal of toxic metal ions from water solution (Crini, 2010). The use of clays as adsorbent have advantages upon many other commercially available adsorbents in terms of low-cost, an abundant availability, high specific surface area, excellent adsorption properties, nontoxic nature, and large potential for ion exchange (Crini and Badot, 2010; Gupta et al., 2013; Rao et al., 2014; Rao et al., 2015). Clays also contain exchangeable cations and anions held to the surface (Miranda-Trevino and Coles, 2003; Crini and Badot, 2010). For these reasons, the attention of scientists worldwide has been focused on using natural or modified clay materials as adsorbent for water treatment.

The uptake of heavy metals by clay minerals involves a series of complex adsorption mechanisms; such as direct bonding between metal cations with the surface of clay minerals, surface complexation, and ion exchange etc., (Churchman et al., 2006; Arnamwong et al., 2016). Clay has a property that shows plasticity through a variable range of water content, which can harden when dried (Das, 2012). The efficiency of adsorption depends on various soil characteristics such as particle size distribution, particulate shape, clay content, moisture content, heterogeneity of soil matrix, density between soil matrix and metal contaminants, magnetic properties, and hydrophobic properties of particle surface (Van et al., 1996; Pollard et al., 2006). Heavy metals have different sorption characteristics and the mechanisms depend on the adsorbents. Clays used as adsorbent show difference in the sequence of selectivity for different metals. One example is lead when compared to other metals, since it is highly attracted and adsorbed by several types of clay (Manahan, 2001).

In many cases, pre-treatment is required to enhance the adsorption capacity of clays and hence modified to increase metal uptake (O'Connell et al., 2010). This pretreatment enhances the surface 
area, pore volume, and number of present active sites on the surface. Through this treatment or modification, the clay minerals become hydrophobic, organophilic, and it thus enhances the uptake of small non-ionic organic compounds (Ismadji et al., 2015). Many forms of treatment can modify clay, with a goal to increase the adsorption capacity of the raw clay material. However, researchers have also present results that treatment or modification did not increase the adsorption properties (Bhattacharyya and Gupta 2009; Al-Jlil and Alsewailem, 2009). In this review, we summarized the different techniques that have been implored for modification and synthesis of novel clay materials.

\section{Clay Modification Techniques}

\subsection{Chemical Treatment}

This process involves the use of both organic and mineral acids, base (alkilinisation), salts and metal oxides for modification of clays achieved through pillaring and intercalation. Chemical treatment is a widely used technique for activation and functionalization of clays (Bhattacharyya and Gupta 2006; Gładysz-Płaska, et al., 2012; Kumar et al., 2012; Shen et al., 2015).

Pillaring is the process by which a layered compound is transformed into a thermally stable microand/or mesoporous material with retention of the layered structure (Schoonheydt and Jacob, 2001). The obtained product is a pillared compound or a pillared layered solid. Pillared clays (PILCs) constitute a special class of pillared layered solids. The goal of the pillaring process is to introduce micro and mesoporosity into clay minerals. This is achieved by combination of clay and a pillaring agent via an ion-exchange reaction, in which a two-dimensional channel network is formed (Schoonheydt and Jacob, 2001). Heating the clays imparts stability to the pillared clay by promoting permanent bonding between the pillar and the layers. The resulting materials have small cavities and a large surface area. These properties, along with their low cost, make pillared clays ideal for use as alternative catalysts to zeolites (Kloprogge et al., 2002). There are numerous oligomeric cations that could be used as pillars, some of which are Al, Zr, Ti, Cr, Fe and Ce (Pergher et al., 1999; Kloprogge et al., 2002). These cations could be used individually or mixed in different ratios (Carriazo et al., 2005; Catrinescu et al., 2011).

Several authors have extensively studied the preparation techniques and adsorption properties of aluminum-pillared clays. Research by Yu et al. (2008) revealed that Carbon modified aluminumpillared montmorillonite has shown good uptake of Cd (II) from an aqueous system. The Cd (II) adsorption followed a mechanism based on second-order kinetics. Adsorption of Cd (II) was low at a $\mathrm{pH}$ level less than 6.0, but uptake increased sharply at a $\mathrm{pH}$ level greater than 6.0. This may be as a result of the relatively low $\mathrm{H}^{+}$concentration on the clay surface as the surface became negatively charged at a higher $\mathrm{pH}$; this could allow for strong bonds with $\mathrm{Cd}$ (II). A study by $\mathrm{Na}$ et al. (2010) also confirmed Ti-pillared montmorillonite as an effective and a promising adsorbent for As (III) and As $(V)$ removal from arsenic contaminated water.

Intercalation is the reversible inclusion or insertion of a molecule or ion into materials with layered structures (Stanley, 2012). The surfaces of clays have been modified through intercalation by different researchers. A meticulous study by Kumar et al. (2012), showed the intercalation of trioctylamine onto sodium montmorillonite for potential adsorption of mercury as a tetrachloromercurate (II) anion. The adsorption was facile in an acidic medium and a $\mathrm{N}_{2}$ adsorption-desorption isotherm study confirmed the mesoporous nature of the adsorbent. The result of their study also showed that the adsorption process was thermodynamically favoured. The adsorption process was correlates to the mechanism involved in the electrostatic interaction between the tetra-chloromercurate (II) anion and the protonated amine in the improved clay.

In the treatment of a pillared Smectite clay, Guerra et al. (2008) collected raw Brazilian Smectitebearing clay samples, and [3-(2-aminoethylamino) propyl] trimethoxy-silane was successfully anchored onto the pillared Smectite; then, active sites were improved in the clay surface through the presence of the $\mathrm{NH}$ groups in the modifying agent intercalated chain. This displayed improved ability for lead sorption.

\subsubsection{Modification with Organic Compounds}

To render layered silicates miscible with polymer matrices, one must convert the hydrophilic silicate surface to an organophilic one, making the intercalation of polymeric chain between silicate layers possible. This can be done by ion-exchange reactions with organic surface active (surfactant) agents (Ozdemir and Yapar, 2009). Several researches have shown that organically modified clay possess 
good and improved adsorption properties. For instance, result of a study on $\mathrm{Cr}$ (VI) removal using batch adsorption techniques conducted by Gładysz-Płaska et al. (2012), exploring the adsorptive properties of the natural red clay after modification by hexadecyl-trimethylammonium bromide (HDTMA) showed improved adsorption properties of the modified clay over the raw red clay. In the advancement of organically modified montmorillonite clay and for the removal of copper, a research work was conducted by Ma et al. (2016) in which organo-montmorillonites (OMts) were modified by a cationic surfactant and a zwitterionic surfactant. The adsorption capacity of the zwitterionic surfactant (Z16) modified montmorillonite towards $\mathrm{Cu}$ (II) was comparable with that of raw montmorillonite. The results of this work provide novel information for developing new effective adsorbents of heavy metals. Smectite was modified using hexadecyltrimethylammonium bromide which an amount to double cationic exchange capacity for the interchangeable sorption of phosphate (V) and $\mathrm{Pb}$ (II) (Bajda et al., 2015). Possible use of montmorillonite modified with polyethyleneimine was investigated by Goncharuk et al. (2010) for the removal of Co (II) and Ni (II) metal ions from aqueous solutions. The increased sorption of cobalt on the modified sorbent being studied (compared with the natural mineral) pointed to the binding of cobalt ions with amine groups attached to the sorbent. It was found that the employment of such a composite sorbent is promising for the purification of medium and highly mineralized wastewaters with a neutral value of $\mathrm{pH}$ (Goncharuk et al., 2010).

In another instance, kaolinite and montmorillonite were modified with tetrabutyl-ammonium (TBA) bromide followed by calcination and used for the adsorption of $\mathrm{Fe}$ (III), Co (II) and $\mathrm{Ni}$ (II) ions from aqueous solution as studied by Bhattacharyya and Gupta (2009). In their report, the calcined TBA clay minerals have a lower adsorption capacity compared to the parent clay minerals at the same experimental conditions; they demonstrated that the reduced adsorption capacities of the calcined TBA clay minerals were attributed the bulky TBA groups that block several negatively charged sites and most likely, the pores. Unuabonah et al. (2008) studied the sorption of $\mathrm{Pb}$ (II) and Cd (II) on sodium tetraborate modified kaolinite clay, and the result of their study showed increase in the sorption capacity of the kaolinite upon modification with sodium tetraborate. The increase in adsorption capacity of the modified clay was attributed to the increase in its cation exchange capacity.

Organically modified clays have been found to possess increased capabilities to remove heavy metals contaminants from aqueous solutions (Aroke and El-Nafaty, 2014). Surfactant modified clays can provide selectivity. They are produced from inexpensive base materials and are chemically regenerable. Therefore, modification of a specific clay mineral with anionic surfactant can produce an efficient adsorbent that is capable of sorbing inorganics from aqueous solutions (Tien et al., 2017). In contrast, reduced efficiency of some organically modified clays adsorbents for adsorption of heavy metals is primarily due to the fact that organic cations compete with metals for adsorption sites on the clay mineral surfaces. For instance, a study was reported on the adsorption of $\mathrm{Pb}$ (II) and $\mathrm{Hg}$ (II) by montmorillonites modified with natural organic cations (Cruz-Guzmana et al., 2006). In their study, the adsorption of $\mathrm{Pb}$ (II) and $\mathrm{Hg}$ (II) was reduced because of the competition between organic cations and heavy metals for adsorption sites and lack of organic functional groups that are capable of interacting with heavy metals.

\subsubsection{Acid Activation}

Treatment of clays with acids replaces exchangeable cations with $\mathrm{H}$ ions and leaching cations out of both tetrahedral and octahedral sites, leaving the $\mathrm{SiO}_{4}$ group intact for binding with cations and anions (Theocharis et al., 1998). Acid activations of clay materials have been widely studied as a form of chemical treatment method for the improvement of heavy metals adsorption properties. The method involves leaching of the clays with either organic or inorganic acids, resulting into disaggregation of clay particles, elimination of mineral impurities, and dissolution of the external layers, thus altering the chemical composition and structure of the clays (Emam et al., 2016). The acid treatment is beneficial in terms of increased surface area, porosity and number of acid sites with respect to the parent clays. The acid treated clays are made up of a mixture of non-attacked clay layers and a hydrous, amorphous, and partially protonated silica phase (Belver, 2002).

Acid activations of several clay materials have been widely studied. Olu-Owolabi et al. (2010) reported the modification of Bentonite clay with a binary mixture of goethite and humic acid for the removal of $\mathrm{Cu}$ (II) and $\mathrm{Cd}$ (II) from aqueous solutions. The modification resulted in an increased 
cation exchange capacity by a binary mixture of goethite and humic acid reagents. An investigation of the adsorption of lead (II) onto montmorillonite clay modified by humic acid under a fixed $\mathrm{pH}$ condition was also conducted by Aziz et al., (2015), the results showed that adsorption of $\mathrm{Pb}$ (II) onto humic acid was high. Li et al. (2010) conducted a research on the influence of low molar mass organic acids, acetic acid, tartaric acid, and citric acid on $\mathrm{Cd}$ (II) and $\mathrm{Pb}$ (II) adsorption by goethite and montmo-rillonite. The effects of the acid concentrations on $\mathrm{Cd}$ (II) and $\mathrm{Pb}$ (II) adsorption were more obvious on goethite than montmorillonite according to the study. In the goethite system, Cd (II) adsorption was better increased by citric acid and tartaric acid than by acetic acid at low acid concentrations. Christidis et al. (1997) also reported that treatment of raw bentonite with hydrochloric acid resulted to an increased surface area of the clay after modification and thereby enhanced the sorption capacity of the clay sorbent in the removal of heavy metal ions from aqueous solutions. Bhattacharyya and Gupta (2006) studied the adsorption of iron oxide, Fe (III), from water by natural and acid activated clays. The study showed that the adsorption increased with $\mathrm{pH}$ until $\mathrm{Fe}$ (III) became insoluble at a $\mathrm{pH}$ level >4.0, and increased adsorption capacity was shown for the acid activated clay minerals when compared to the untreated clay minerals.

However, treatment of clay with acids may also result in low adsorption capacity of the clay. For instance, three types of local clays: Tabuk, Baha, and Khaiber, were tested for their abilities to adsorb $\mathrm{Pb}$ (II) from wastewater. The clays were then treated with hydrochloric acid to activate the adsorption sites within clay particles. Untreated Tabuk clay had the largest adsorption capacity $(30 \mathrm{mg}$ lead/g clay) in comparison to those of Baha and Khaiber clays. The adsorption of the metal on acid-activated clays was not enhanced and low compared to those of the untreated clays (Al-Jlil and Alsewailem, 2009).

\subsubsection{Salt Modification}

Modification of clay soil using both organic and inorganic salts, have been studied by several researchers. For instance, Ma et al. (2011) studied Phosphate-modified montmorillonite (PMM) for the removal of $\mathrm{Co}^{2+} \mathrm{Sr}^{2+}$, and $\mathrm{Cs}^{+}$from an aqueous solution. They reported that the surface properties of the modified clay were improved; Freundlich model best explained the process of the adsorption, indicating the heterogeneous surface property of PMM. Sorptions of $\mathrm{Co}^{2+}$ and $\mathrm{Sr}^{2+}$ were strongly dependent on the solution $\mathrm{pH}$. The nature of $\mathrm{Co}^{2+}$ sorption was endothermic, while $\mathrm{Cs}^{+}$was exothermic. The strongly $\mathrm{pH}$-dependent sorption of $\mathrm{Co}^{2+}$ indicated that surface complexation was the main mechanism of $\mathrm{Co}^{2+}$ sorption onto PMM. Optimisation of a two-stage batch adsorption of $\mathrm{Pb}$ (II) ions onto tripolyphosphate-modified kaolinite clay experiment was carried out by Unuabonah and Adebowale (2009). The mechanism of their study suggested that $\mathrm{Pb}$ (II) ion adsorption possibly took place at the negatively charged O-P-O sites. The presence of up to three negative charged sites per molecule of pentasodiumtripoly-phosphate adsorbed onto the kaolinite clay may have contributed to enhancing the adsorption capacity of the TPP modified adsorbent.

More so, the results of a Modified kaolinite clay with 25\% (w/w) aluminum sulphate and unmodified kaolin used as an adsorbent to remove $\mathrm{Pb}$ (II) from an aqueous solution showed that the amount of $\mathrm{Pb}$ (II) adsorbed onto modified kaolin $(20 \mathrm{mg} / \mathrm{g})$ was more than 4.5 -fold than that adsorbed onto unmodified kaoline $(4.2 \mathrm{mg} / \mathrm{g}$ ) under the optimized condition (Qin et al., 2009). High asdsorption of $\mathrm{Cu}$ (II), $\mathrm{Zn}$ (II), Cd (II), and $\mathrm{Pb}$ (II) onto sulphate modified goethite have been demonstrated (Swedlund et al., 2009). Kaolinite clay, in bright white lumps collected from from Ubulu-Ukwu, Delta State, Nigeria, was modified with phosphate (P-modified) and sulphate anion and thereafter used to adsorb some heavy metals $(\mathrm{Pb}, \mathrm{Cd}, \mathrm{Zn}$ and $\mathrm{Cu})$ from aqueous solution of the metals. The metal ions showed greater affinity for the modified kaolinite clay mineral compared with the unmodified kaolinite clay. The phosphate modified clay however possesses greater adsorption capacity than sulphate modified clay. The order of adsorption of $\mathrm{P}-\bmod$ is presented as follows: $\mathrm{P}-\bmod \mathrm{Pb}>\mathrm{P}-$ $\bmod \mathrm{Cu}>\mathrm{P}-\bmod \mathrm{Zn}>\mathrm{P}$-modCd. Desorption studies revealed that the P-modified clay showed a very strong ability to specifically adsorb lead, copper and zinc and are therefore poorly desorbed while all the metals were easily desorbed from the unmodified sorbent. In another treatment, a Japanese volcanic soil called Akadama clay was functionalized with metal salts $\left(\mathrm{FeCl}_{3}, \mathrm{AlCl}_{3}, \mathrm{CaCl}_{2}, \mathrm{MgCl}_{2}\right.$, and $\mathrm{MnCl}_{2}$ ) and used to adsorb Cr (VI) from an aqueous solution (Ji et al., 2015). The adsorption showed little dependence on the $\mathrm{pH}$ of solution. Result of also showed that $\mathrm{Cr}$ (VI) was best removed by $\mathrm{FeCl}_{3}$. 


\subsubsection{Metal Oxide Functionalization (Oxidative Modification)}

The oxidation modification of clays leads to the formation of colloid-sized particles. Colloids are particles with linear dimensions between 0.001 and $1.0 \mu \mathrm{m}$ (Hiemenz, 1986). The high specific surface area possessed by the colloid particles is an essential characteristic in adsorption phenomena. It is therefore important that the colloid particles remain stable over a period. The colloid must also be stable or resistant to Ostwald ripening or coagulation (Mayer and Jarrell 1996). Ostwald ripening is the process by which larger particles grow at the expense of smaller ones (Finsy, 2004). This occurs because the smaller particles being energetically less stable than the larger ones dissolve and precipitate onto larger particles. It has been demontrated that dissolved organic matter and inorganic anions such as phosphate and silicate inhibit the Ostwald ripening of $\mathrm{Fe}$ oxides (Liang and Morgan, 1990; Schwertmann and Cornell, 1991). Also, the presence of inorganic anions like phosphate and silicate is believed to make Fe oxide negatively charged and play important roles in stabilizing colloids (Sigg and Stumm, 1981; Anderson \& Benjamin, 1985; Liang \& Morgan, 1990). Si in the structure of ferrihydrite is capable of inhibiting the transformation of ferrihydrite to more crystalline oxides and exerts a strong influence on the crystallinity of Si-containing ferrihydrite (Ford et al., 2006). Ferrihydrite-modified clay could be produced by oxidizing the Fe (II) product slowly in the npresence of dissolved silica to the Fe (III) species (Mayer \& Jarrell, 1996). The final product has been identified to be one of two Fe oxides (lepidocrocite or ferrihydrite), depending on the initial concentration of dissolved silica (Schwertmann and Thalmann, 1976; Schwertmann et al., 1984; Tipping et al., 1989). The $\mathrm{Si} / \mathrm{Fe}$ molar ratio is important in determining which of the Fe oxides would be formed during the oxidation of Fe (II).

In recent years, series of aluminum and iron oxide modified Smectites have been used for comparative study of their effectiveness on heavy metal adsorption from water (Franco et al., 2016). Except for Hg (II) sorption, the starting Smectites and the obtained materials displayed higher metal adsorption properties in comparison to that of carbon that is used as the reference in their study. The adsorption properties of raw bentonite were further improved by modification with manganese oxide. The high adsorption performance exhibited by manganese oxide modified bentonite (MMB) was attributed to an increased surface area and a higher negative surface charge after modification for successful removal of traced $\mathrm{Cu}$ (II) from an aqueous solution (Eren and Afsin, 2008). Sari and Tuzen (2013) studied the adsorption of silver from aqueous solution using both raw (RV) and manganese oxide-modified vermiculite (Mn-MV). Results of their study showed that the adsorption surface of $\mathrm{RV}$ increased approximately 10 times after the modification because of the increase in negative charge onto the sorbent surface (Sari and Tuzen 2013).

\subsubsection{Modification by Polymers}

Clay minerals such as kaolin can also be modified by the use of polymers. This could be achieved through surface doping or chemical grafting in which the polymer is allowed to interact with the clay to form polymer-clay hybrid composites (Toor, 2010). Chen et al., (2005) proposed polyacrylamide as a polymer to be used for clay modification. Polymer clays are classified into three viz. conventional composites, intercalated composites and exfoliated composites (Masinga, 2013). The loading of polymers into clay could produce materials with enhanced adsorption properties.

Chitosan is a natural polycationic biopolymer that can form chelate with heavy metals through its amino and hydroxyl groups and its nano-composites with clays and zeolites are used for heavy metals adsorption. However, chitosan has a low surface area, with weak chemical and mechanical properties. Thus, modifications are required to overcome these limitations. On the other hand, clay has a lamellar structure with negatively charged surfaces that can interact with polycationic chitosan to form polymer-clay hybrid. Chitosan-functionalized closite 10A (Pandey and Mishra, 2011) montmorilonite (Fan et al., 2006; Bleiman and Mishael, 2010) perlite (Hasan et al., 2003; Hasan et al., 2008; clinoptilolite, 2010, alumina (Boddu et al., 2003) and bentonite (Futalan et al., 2012) have been used for the adsorption of heavy metals from aqueous medium. The functional groups of chitosan $\left(-\mathrm{NH}_{2}\right.$ and $-\mathrm{OH}$ ) interact with heavy metals in the compounds. Chitosan-layered nanocomposites interaction with metal cations occurs through $-\mathrm{OH}$ and $-\mathrm{NH}_{2}$ groups of chitosan and the maximum adsorption capacity values of these adsorbents completely depend on the used layered compounds (Kalyani et al., 
2005). Wang et al. (2009) reported the use of chitosan-g-poly (acrylic acid)/attapulgite (CTS-gPAA/APT) composites for the adsorption of $\mathrm{Cu}^{2+}$. Results showed that there was reaction between attapulgite (APT) and the CTS-g-PAA polymer. Adsorption experiments carried out at $\mathrm{pH} 5.5$ showed fast sorption of the $\mathrm{Cu}^{2+}$ and more than $90 \%$ of the metal ion was adsorbed after 15 minutes. FTIR spectra of CTS-g-PAA/APT compound before and after the adsorption of $\mathrm{Cu}^{2+}$ showed possible chemical interaction between the $-\mathrm{NH}_{2},-\mathrm{OH}$ groups of chitosan, $-\mathrm{COOH}$ groups of PAA in the composites and the $\mathrm{Cu}^{2+}$. Similarly, methacrylic acid grafted chitosan/bentonite (Abdel Khalek et al., 2012), Chitosan-g-poly (acrylic acid)/vermiculite (Wang and Wang, 2012) and humic acidimmobilized-amine modified polyacrylamide immobilized on bentonite (Anirudhan and Suchithra, 2010) have been reportedly used for the adsorption of various heavy metal ions from their respective aqueous solution.

Synthesis of a novel superabsorbent composite was achieved by copolymerization reaction of partially neutralized acrylic acid (AA) on bentonite micropowder using $\mathrm{N}, \mathrm{N}^{\prime}$-methylenebisacrylamide as a crosslinker (Bulut et al., 2009). The results of the study showed high maximum coverage capacity values for sorption of $\mathrm{Pb}^{2+}(1666.67 \mathrm{mg} / \mathrm{g}), \mathrm{Ni}^{2+}(270.27 \mathrm{mg} / \mathrm{g}), \mathrm{Cd}^{2+}(416.67 \mathrm{mg} / \mathrm{g})$ and $\mathrm{Cu}^{2+}(222.22$ $\mathrm{mg} / \mathrm{g})$.

\subsection{Biogenic Modification (Fortification with Organic Biomasses and Composites)}

Fortification of clay with organic biomass and composites could possibly enhance heavy metals adsorption by improving the surface area of the clay, thereby, providing additional reactive sites for cation exchange and/or surface complexation. Akpomie et al. (2017) investigated the effect of cassava peel modified kaolinite clay compared to the unmodified kaolinite clay on the adsorption of $\mathrm{Cr}$ (III) ion. The result showed the suitability of cassava peel modified kaolinite clay for chromium ion sorption from aqueous solution.

Plantain peels are the primary waste products of plantain fruit constituting approximately $40 \%$ of it (Akinsami et al., 2015). The presence of suitable properties and components contained in plantain peel has made it an acceptable biosorbent for removal of heavy metals and other inorganic contaminants. Venkateswarlu et al. (2013) prepared a cheap and eco-friendly $\mathrm{Fe}_{3} \mathrm{O}_{4}$ magnetic nanoparticles adsorbent using plantain peel extract via the biogenic method, the adsorbent was shown to possess high BET surface area and excellent magnetic response attribute. Opeolu and Fatoki (2012) studied the adsorption and desorption potential of plantain peel biomass for the removal of $\mathrm{Zn}^{2+}$ ions from aqueous solution. The result from their study showed an excellent uptake of the metal by the adsorbent. The low cost and abundance and high efficiency of biogenic adsorbents cannot be overemphasized which makes them applicable industrially for adsorption purposes. Sanusi et al. (2016) demonstrated that feldspar clay modified with carica papaya seed showed increased the adsorption; the adsorption capacity of feldspar clay from $18.26 \mathrm{mg} / \mathrm{g}$ to $45.81 \mathrm{mg} / \mathrm{g}$ for $\mathrm{Pb}$ (II) from $12.57 \mathrm{mg} / \mathrm{g}$ to $46.18 \mathrm{mg} / \mathrm{g}$ for $\mathrm{Cu}$ (II) at $308 \mathrm{~K}$ upon modification. Increasing temperature and initial metal ions concentration was found to have resulted to increased adsorption of both metals onto the adsorbent.

\subsection{Mechano-Chemical Treatment}

Mechano-chemistry is the coupling of mechanical and chemical phenomena on a molecular scale and includes mechanical breakage, chemical behavior of mechanically stressed solids, and polymer degradation under shear etc., (Munnings et al., 2014). The method of ball milling is a widely used process in which mechanical force is used to achieve chemical processing and transformation (Carlier et al., 2013). Mechanochemical transformation eliminates the use of many solvents which makes the whole process environmentally friendly (Lim, 2016).

Mechano-chemical phenomena have been applied for clay modification. For instance, Hongo et al. (2012) carried out a research on vermiculite clay which was subjected to mechano-chemical treatment using a vibration mill. The mechano-chemical treatment led to a reduction in the particle size and a significant increase in the surface area. The mechano-chemical treatment of vermiculite resulted in a dramatic improvement in the lead (II) adsorption capacity. The removal of $\mathrm{Pb}$ (II), $\mathrm{Cd}$ (II), $\mathrm{Cu}$ (II) and $\mathrm{Zn}$ (II) from aqueous solutions using unmodified and modified (mechano-chemically activated) Serbian interstratified montmorillonite/kaolinite clay was investigated by Ksenija et al. (2013) and the results of their study showed that the modified clay exhibited greater equilibrium adsorption capacity 


\subsection{Physical Method (Thermal Treatment)}

Physical method of clay modification could be achieved either by calcination or microwave heating. These methods are applied in order to disrupt the chemical structure of the clay material. The clay material is usually subjected to a very high temperature capable of breaking some chemical bonds and altering the arrangement of molecules in the lattice structure of the clay.

\subsubsection{Calcination}

This involves the exposure of the materials to high temperature capable of breaking the bonds of the components contained in the substance. This can also be referred to as conventional heating method of activation (Itodo et al., 2010). Clays are strongly dependent on temperature, and the high temperature treatment of clays destructs the crystalline structure of the clay minerals (Ionescu et al., 2011). Conventional heating technique have been regarded as one of the most adopted for the preparation and activation of adsorption materials among others, in which heat is transferred via convection, conduction and radiation mechanisms (Hesas et al., 2013). In the conventional heating of materials, the outermost parts experience the energy before the interiors, stimulating a thermal gradient amid the inner and the outer surface of individual particle (Thostensen and Chou 1999; Yadoji et al. 2003). This result to heterogeneous microstructure of materials at high heating temperature, high energy consumption and time wasting as limitations compared to other techniques (Oghbaei and Mirzaee, 2010). It could also result to overheating of the materials causing substrate and reagent degradation (Lidstrom et al., 2001).

\subsubsection{Microwave Heating}

The preparation of cost-effective adsorption materials can be considered on the basis of the starting materials, energy consumed and time expended in synthesis of such materials. Almost all reactions have been tested under classical conditions (thermal heating) for comparison with reactions that proceeds in the microwave field which is an improved alternative for conventional heating. It has been observed from experimental results that microwave-initiated chemical reactions occur at faster rates as great as 1000-folds of the conventional methods (Hayes, 2004).

In chemistry, microwave radiation has saved energy in chemical synthesis and production of low-cost adsorbents (Hesas et al., 2013). The principle of microwave irradiation heating is based on the fact that most molecules possess a dipole or are ionic in nature which results into orientation or movement of the poles upon interaction with the microwaves. A dipole is sensitive to external electric field and attempts to align itself with the field when rotated and in the presence of an alternating current. Hence, the electric field is reciprocated at individual variation leading to dipoles moving together to suit the reciprocated electric field Jauhari et al., 2012); thus initiating rotational and frictional forces between the molecules which dispel as internal uniform heating within the medium. Microwave radiation just like other electromagnetic radiation can be understood based on two phenomena namely viz. electric field (accountable for dielectric heating) and magnetic field. The heating is achieved through two primary pathways which are dipolar polarization and conduction mechanisms (Lidstrom et al., 2001). The irradiation frequency $(2450 \mathrm{~Hz})$ of microwave electric field that is commonly used alternates at the speed of $4.9 \times 109 /$ second. Therefore, microwave heating is said to be influenced directly by the dielectric characteristics of the material, namely: dielectric constant and dielectric loss.

Studies have reported that changes occur in the properties of natural clay after thermal treatment at various heated temperatures (Diffo et al., 2015). In a study, Elimbi et al. (2011) reported the calcination temperature of kaolin to be $700{ }^{\circ} \mathrm{C}$ at which geopolymers with optimal characteristics were obtained. In another study, Castelein et al. (2002) observed the transformation of kaolin into mullite under thermal influence. Kounou et al. (2015) conducted a study on Metakaolinite which was obtained from kaolinite clay soils from the South Western Region of Cameroon by heating $20 \mathrm{~g}$ of kaolinite at a temperature of $700{ }^{\circ} \mathrm{C}$. The clay was used as an adsorbent to study its adsorptive capacities on the removal of zinc (II) ions. The adsorption mechanism confirmed that the physical and chemical adsorption processes controlled the zinc (II) ion uptake onto the two adsorbents (Metakaolinite and raw kaolinite). Throughout their study, it was observed that metakaolinte was an excellent adsorbent for $\mathrm{Zn}$ (II) removal compared to kaolinite.

A multi technique was used to investigate the interaction of $\mathrm{Cr}$ (VI) species with pre-fired brick clay as studied and reported by Priyantha and Bandaranayaka (2011), they found that Cr (VI) adsorption by fired brick clay was strongly dependent on the firing temperature as the maximum adsorption was 
found at $200{ }^{\circ} \mathrm{C}$. Research by Rao and Kashifuddin (2012) showed that ball clay exhibited an excellent adsorption capacity toward Cd (II) ions after the sample was heated at $200{ }^{\circ} \mathrm{C}$. The result of their research showed that percentage (\%) adsorption of the fired clay decreased with increasing temperature from $200-1000{ }^{\circ} \mathrm{C}$. However, some studies also confirm the endothermic nature of clay. For example, the maximum adsorption capacities of three types of Saudi clay were found to have increased with temperature increase (Alshammari 2015). The study concluded that adsorption process of three types of natural Saudi clays to remove cobalt ions was endothermic Alshammari. Another investigation supported this result, in which spent activated clay (SAC), a natural waste, produced in Refinery Company, was thermally treated by pressure steam treatment and then used as an adsorbent to remove $\mathrm{Cr}$ (VI). The study proved its beneficial use in wastewater treatment (Weng et al., 2008).

Bhattacharyya and Gupta (2009) demonstrated the modification of Kaolinite and montmorillonite with tetrabutylammonium (TBA) bromide followed by calcination and used for the adsorption of $\mathrm{Fe}$ (III), Co (II), and Ni (II) ions from their respective aqueous solution. However, in their study, the calcined TBA clay minerals possess a lower adsorption capacity compared to the raw clay minerals at the same experimental conditions. The result of the study also showed that the reaction of kaolinite with TBA decreased the adsorption of Fe (II) by $55 \%$, Co (II) by $47 \%$, and Ni (II) by $44 \%$ while the adsorption capacity of the calcined TBA-montmorillonite was reduced by 44,41 and $42 \%$ of the raw clay for removal of $\mathrm{Fe}$ (III), Co (II), and Ni (II), respectively. The reduction in adsorption capacity of the calcined clays could be as a result of the bulky TBA groups that block several negatively charged sites and most likely, also the pores.

\section{CONCLUSION}

Clay materials have shown excellent potential for the removal of metal pollutants without any modifications, but in many studies, their removal capacities were improved through different modification techniques. Treatment techniques such as chemical, physical (thermal), mechanochemical and fortification with organic biomasses and composites have been successfully applied to modify clay soils with the aim of improving the heavy metals adsorption capacity of the soils.

\section{REFERENCES}

[1] Abdel-Khalek, M.A., Mahmoud, G.A. and El-Kelesh, N.A. (2012). Synthesis and caracterization of polymethacrylic acid grafted chitosan-bentonite composite and its application for heavy metals recovery. Chem. Mater. Res. 2, 1-12.

[2] Abou-El-Sherbini, K. and Hassanien, M. (2010). Study of organically-modified montmorillonite clay for the removal of copper (II), Journal of Hazard of Material. 184, 654-661.

[3] Achmed, A., Kassim J., Suan, T.K., Amat, C., and Seey, T.L. (2012). Equilibrium, Kinetic and thermodynamic studies on the adsorption of direct dye unto a novel green adsorbent developed from Ucaria gambir extract, Journal of physical science, 23(1), 1-13.

[4] Adebowale K.O., Unuabonah I.E. and Olu-Owolabi B.I. (2003). Adsorption of Some Heavy Metals on Sulphate and Phosphate Modified Kaolinite Clay United Nations Educational Scientific and Cultural Organization and International Atomic Energy Agency.

[5] Ahmaruzzaman, M. (2011). Industrial wastes as low-cost potential adsorbents for the treatment of wastewater laden with heavy metals, Advanced Colloid Interface Science. 116, 36-59.

[6] Akinola O.O. and Ademilua, O.L. (2014). Compositional Features and Functional Industrial Applications of the Lateritic Clay Deposits in Oye-Ekiti and Environs, Southwestern Nigeria. The International Journal of Science and Technoledge 23, 21 - 919.

[7] Akinsanmi, A. O., Oboh G., Akinyemi, J. A and Adefegha, A. S. (2015). Assessment of the Nutritional, Anti nutritional and Antioxidant capacity of Uripe, ripe, and over ripe Plantain (Musa paradisiaca) Peels, International Journal of Advanced Research, 3(2), 63-72.

[8] Akinyemi, J. A. and Adefegha, A. S. (2015). Assessment of the Nutritional, Anti nutritional and Antioxidant capacity of Uripe, ripe, and over ripe Plantain (Musa paradisiaca) Peels, International Journal of Advanced Research, 3(2), 63-72.

[9] Akpomie, K.G., Odewole, O.A., Ibeji, C.U., Okagu., O.D. and Agboola., I.I. (2017). Enhanced Sorption of Trivalent Chromium unto Novel Cassava Peel Modified Kaolinite Clay. Der Pharma Chemica, 9(5), 4855. ISSN 0975-413X

[10] Alina, K. (2011). Trace Elements in Soils and Plants, Fourth edition. Tailor and Francis Group. Retrieved 17 June 2015. 
[11] Alinnor, I. (2007). Adsorption of heavy metal ions from aqueous solution by fly ash. Fuel, 86(5): p. 853-857.

[12] Al-Jlil, S.A. and Alsewailem, S.A. (2009). Saudi Arabian clays for lead removal in waste-water, Applied Clay Science. 42: 671-674.

[13] Allen,J.P\& Torres, I.G.(1991). Physical Separation Techniques for ContaminatedSediment, in Recent Developments in Separation Science, N.N. Li, Ed., CRC Press, West Palm Beach, FL, Vol V.

[14] Amodio-Cocchieri, R., Arnese, A., Prospero, E., Roncioni, A., Barulfo, L., Ulluci, R. and Romano V. (1996) Lead in human blood form children living in Campania, Italy. Journal of Toxicology and Environmental Health. PubMed 47:311-320.

[15] Andrade, J.Á., Augusto, F. and Jardim, I.C.S.F (2010). Biorremediação de solos contaminados porpetróleo e seus derivados. Eclética química;35(3) 17-43.

[16] Anirudhan, T.S.; Suchithra, P.S. Heavy metals uptake from aqueous solutions and industrial wastewaters by humic acid-immobilized polymer/bentonite composite: Kinetics and equilibrium modeling. Chem. Eng. J. 2010, 156, 146-156.

[17] Arnamwong, S., Suksabye, P. and Thiravetyan, P. (2016). Using Kaolin in Reduction of Arsenic in Rice Grains: Effect of Different Types of Kaolin, pH and Arsenic Complex. Bull Environ Contam Toxicol. 96(4):556-61. doi: 10.1007/s00128-016-1740-8.

[18] Aroke U.O, El-Nafaty U.A, Osha O.A (2013). Properties and characterization of Kaolin Clay from Alkaleri, North-Eastern Nigeria. International Journal of Emerging Technology and Advance Engineering 3(11):387-392.

[19] Arruti A, Fernández-Olmo I, Irabien A. (2010). Evaluation of the contribution of local sources to trace metals levels in urban PM2.5 and PM10 in the Cantabria region (Northern Spain). Journal of Environmental Monitoring. PubMed;12(7):1451-1458.

[20] Assink, J.W. and Rulkens, W.H. (1989), “Cleaning Soils Contaminated with Heavy Metals,"Hazardous and Industrial Wastes, Proceedings of the 21st Mid Atlantic Industrial Waste Conference, Cole, C.A and Long, D.A. (Eds.), Technomics, Lancaster, PA.

[21] Awokunmi, E.E and Asaolu, S.S. (2017). Physicochemical and performance evaluation of natural and modified Ire-Ekiti clay: Emerging substrate in the de-fluoridation of drinking water. Journal of physical and chemical sciences 5: 2348-3270

[22] Aziz, H.A., M.N. Adlan, and K.S. Ariffin, (2008). Heavy metals (Cd, Pb, Zn, Ni, Cu and Cr (III)) removal from water in Malaysia: Post treatment by high quality limestone. Bioresource Technology, 99(6): p. 15781583.

[23] Aznárez, A., Delaigle, R., Eloy, P., Gaigneaux, E.M., Korili, S.A., and Gil, A (2015). Catalysts based on pillared clays for the oxidation of chlorobenzene. Catalyst Today. 246, 15-27.

[24] Babel, S. and T.A. Kurniawan (2003). Low-cost adsorbents for heavy metals uptake from contaminated water: a review. Journal of hazardous materials, 97(1): p. 219-243.

[25] Bajda, T., Szala B., and Solecka, U. (2015), Removal of lead andphosphate ions from aqueous solutions by organo-smectite. Environmental Technology. 36 2872-2883.

[26] Balasubramanian R, Perumal S.V, and Vijayaraghavan K. (2009), Equilibrium isotherm studies for the multicomponent adsorption of lead, zinc, and cadmium onto Indonesian peat, Industrial Engineering and Chemical Resources. 48 2093-2099.

[27] Bansode, R., et al. (2003). Adsorption of metal ions by pecan shell-based granular activated carbons. Bioresource Technology. 89(2): p. 115-119.

[28] Barakat, M. (2005). Adsorption behavior of copper and cyanide ions at $\mathrm{TiO}_{2}$-solution interface. Journal of Colloid and Interface Science. 291(2): p. 345-352.

[29] Bear, F.E, (1965). Chemistry of the Soil, Second ed., Reinhold Publishing.

[30] Benefield, L.D., Judkins, J.F. and We, B.L. (1982). Process chemistry for water and wastewater treatment 1982: Prentice Hall Incorporation.

[31] Benoff, S., Jacob, A., and Hurley, I.R. (2000). Male Infertility and environmental exposure to lead and cadmium, Human Reproduction Update. 6 107-121.

[32] Bentahar, Y., Hurel, C., Draoui, K., Khairoun, S., and Marmier N (2016), Adsorptive properties of Moroccan clays for the removal of arsenic (V) from aqueous solution, Applied Clay Science 119 385-392.

[33] Berger, T.M. (2005) Biorremediação de solos contaminados com hidrocarbonetos totais de petróleo - enfoque na aplicação do processo Terraferm. PhD Thesis. Universidade Federal do Rio Grande do Sul. 
[34] Bhattacharyya, K.G. and Gupta S.S. (2006). Adsorption of Fe (III) from water by natural and acid activated clays: studies on equilibrium isotherm, kinetics and thermodynamics of interactions, Adsorption, 12: 185-204.

[35] Bhattacharyya, K.G. and Gupta, S.S. (2009). Calcined tetrabutylammonium kaolinite and mont-morillonite and adsorption of $\mathrm{Fe}(\mathrm{II}), \mathrm{Co}(\mathrm{II})$ and $\mathrm{Ni}(\mathrm{II})$ from solution, Applied Clay Science, 46216-46221.

[36] Bishop, P., Gress, D., and Olafsson, J. (1982), "Cement Stabilization of Heavy Metals: Leaching Rate Assessment," Industrial Wastes-Proceedings of the 14th Mid-Atlantic Industrial Waste Conference. Technomics, Lancaster, PA.

[37] Boddu, V.M.; Abburi, K.; Talbott, J.L.; Smith, E.D. Removal of hexavalent chromium from wastewater using a new composite chitosan biosorbent. Environ. Sci. Technol. 2003, 37, 4449-4456.

[38] Bourliva, A., Michailidis K., Sikalidis C., and Trontsios G. (2004). Industrial application of UF membrane in the pretreatment for RO system. Journal of Membrane Science and Technology. 4: 9.

[39] Bouzoukis, G. J. 1962. Hydrometer method improved for making particle size anaIysis of soils. Agronomy Journal 54:464-465.

[40] Bradl, H. (2002). Heavy Metals in the Environment: Origin, Interaction and Remediation Volume 6.London: Academic Press.

[41] Brigatti, M.F., Galan, E. and Theng, B.K.G. (2013). Structure and Mineralogy of Clay Minerals, Developments in Clay Science, vol. 5A, Elsevier Press, pp. 21- 68.

[42] Bulut, Y.; Akçay, G.; Elma, D.; Serhatli, I.E. Synthesis of clay-based superabsorbent composite and its sorption capability. J. Hazard. Mater. 2009, 171, 717-723.

[43] Cameselle, C. and Reddy, K. R. (2012). Electrochim. Acta 86 10-12.

[44] Carlier, L. (2017). Use of co-grinding as a solvent free synthesis: investigation of the mechanism in the case of dibenzophenazine. Powder technology. 2013, 240, $41-47$.

[45] Carriazo, J., Guélou, E., Barrault, J., Tatibouët, J.M., Molina, R., and Moreno, S. (2005) Catalytic wet peroxide oxidation of phenol by pillared clays containing Al-Ce-Fe. Water Resources. 2005, 39, 3891-3899.

[46] Carvalho, C.M., Lu, J., Zhang, X., Arner, E.S., and Holmgren, A. (2010). Effects of selenite and chelating agents on mammalian thioredoxin reductase inhibited by mercury: Implications for treatment of mercury poisoning. FASEB Journal. (CrossRef) (PubMed.) 25, 370-381.

[47] Castelein, O., Aldon L., Olivier-Fourcade J., Jumas J.C., Bonnet, J.P. and Blanchart P. (2002) Fe Mossbauer study of iron distribution in a raw kaolinite clay: Influence of temperature and the heating rate. Journal of European Ceramics Society, 22, 1767-1773.

[48] Catrinescu, C., Arsene, D., and Teodosiu, C. (2011). Catalytic wet hydrogen peroxide oxidation of parachlorophenol over Al/Fe pillared clays (AlFePILCs) prepared from different host clays. Applied Catalyst., $101,451-460$.

[49] Centeno., J.A., Tchounwou, P.B., Patlolla, A.K., Mullick, F.G., Muraka,t L., Meza, E., Gibb, H., Longfellow, D. and Yedjou C.G (2005). Environmental pathology and health effects of arsenic poisoning: a critical review. In: Naidu R, Smith E, Smith J, Bhattacharya P, editors. Managing Arsenic In the Environment: From Soil to Human Health. CSIRO Publishing Corporation Adelaide, Australia.

[50] Chaari,I.,Medhioub.,M,Jamaoussi.,F(2011),Use of clay to remove heavy metals from Jebel chakir landfill leachate, Journal of Applied Science and Environmental Sanitation. (CrossRef) 6143148.

[51] Chen, L. and Chen, Q. (2003). Industrial application of UF membrane in the pretreatment for RO system [J]. Membrane Science and Technology. 4: p. 009.

[52] Churchman, G.J., Conner, J.R. (1990), Chemical Fixation and Solidification of Hazardous Wastes, Van Nostrand Reinhold, New York.

[53] Churchman, G.J., Gates, W.P., Theng, B.K.G., Yuan, G., Bergaya, F., and Lagaly, G. (2006) (Eds.), Clays and Clay Minerals for Pollution Control. Development in Clay Science, Elsevier Press, vol. 1, 110-118.

[54] Crini, G. (2006). Non-conventional low-cost adsorbents for dye removal: A review. Bioresource Technology 97, 1061-1085. DOI:10.1016/j.biortech.2005.05.001

[55] Crini, G. and Badot, P. N. (2010). Sorption Process and Pollution, Conventional and Non-Conventional Sorbents for Pollutant Removal from Wastewaters, University of Franche-Comté Presses.

[56] Crittenden, J.C., Li, K.E., Daisuke, M, and Paul W., (2008). Understanding and Improving Process Performance of Advanced Oxidation Processes (AOPS). research gate

[57] Cruz-Guzmana, M., Celis, R., Hermosina, M.C., Koskinen, W.C., Nater, E.A. and Cornejo, J. (2006). Heavy metal adsorption by Montmorillonites modified with natural organic cations, Soil. Sci. Soc. Am. 70: 215-221.Das, B.M. (2012). Introduction to Geotechnical Engineering, , Cram101 Incorporation, Publication and services. first edition. 
[58] Dawodu, F.A., Akpomie G.K., Ejikeme M.E., and Ejikeme P.C.N., (2012). The use of Ugwuobaclay as an adsorbent for Zinc (II) ions from solution, Internation Journal. Multidisclipine Science and Engineering. 3 13-18.

[59] Deliyanni, E., E. Peleka, and K. Matis. (2007). Removal of zinc ion from water by sorption onto iron-based nanoadsorbent. Journal of hazardous materials, . 141(1): p. 176- 184.

[60] Deng, L.L., Yuan, P., Liu, D. and Liu, Z.W. (2017).Effects of microstructure of clay minerals, montmorillonite, kaolinite and halloysite, on their benzene adsorption behaviors.Applied. Clay Science., $143,184-191$.

[61] Dermont, G.. (2008) Metal-contaminated soils:remediation practices and treatment technologies. Practice Periodical of Hazardous, Toxic, and Radioactive Waste Management. 12(3): p. 188-209.

[62] Detoni, C., Bertella, F., Souza, M.M.V.M., Pergher, S.B.C. and Aranda, (2014) D.A.G. Palladium supported on clays to catalytic deoxygenation of soybean fatty acids. Applied. Clay Science. (CrossRef), 95, 388-395.

[63] Diffo, K.B.B., Elimbi, A.,Cyr, M., Manga, J.D. and Kouamo, H.T. (2015) Effect of the rate of calcination of kaolin on the properties of metakaolin-based geopolymers, Journal of Asian Ceramic Societies 3, 130-138.

[64] Dizge, N., Keskinler, B. and H. Barlas, (2009). Sorption of Ni (II) ions from aqueous solution by Lewatit cation-exchange resin. Journal of hazardous materials, 167(1):p.915-926.

[65] Djebbar, M., Djafri, F., and Bouchekara, M. (2014). Equilibrium, Langmuir Isotherms and Thermodynamic Studies for Adsorption of Cu(II) on Natural Clay, Springer,

[66] Duffus J.H. (2002). Heavy metals-a meaningless term? Pure and Applied Chemistry.74(5):793-807.

[67] Eba, F., Gueu, S., Eya'A-Mvongbote A., Ondo J. A., Yao B. K., Ndong N. J., and Kouya, B.R. (2010). Evaluation of the absorption capacity of the natural clay from Bikougou (Gabon) to remove Mn (II) from aqueous solution. International Journal of Engineering Science and Technology 10, 5001-5016

[68] Elimbi, A., Tchakoute, H.K. and Njopwouo, D. (2011) Effects of calcination temperature of kaolinite clays on the properties of geopolymer cements, Construction and Building Materials, 25, 2805-2812

[69] Elliot, H.A. and Brown, G.A. (1989), "Comparative Evaluation of NTA and EDTA for Extractive Decontamination of Pb-Polluted Soils," Water, Air, and Soil Pollution, 45:361-369.

[70] Eloussaief, M. and Benzina, M. (2010), Efficiency of natural and acid-activated clays in the removal of $\mathrm{Pb}$ (II) from aqueous solutions, Journal of Hazard Material. 178 753-757.

[71] El-Sayed G.O., Aly H.M., and Hussien S.H. (2011).Int. J. Res. Chem. Environ., 1,132.

[72] Eren,E.\&AfsinB.,(2008).s AninvestigationofCu(II)adsorptionbyrawandacid activated bentonite:acombined potentiometric, thermodynamic, XRD, IR,DTA study, Journal of Hazardous Material 151 682-691.

[73] Fergusson J.E, (1990). The Heavy Elements:Chemistry,Environmental Impact and Health Effects. Oxford: Pergamon Press.

[74] Fjar E, Holt R.M, Raaen A.M, Risnes, R. (2008), Horsrud P, Petroleum Related Rock Mechanics, Developments in Petroleum Science, second ed., vol. 53, Elsevier Press, p. 514.

[75] Forgacs, E., Cserhati, T. and Oros, G. (2004). Removal of synthetic dyes from wastewaters: A review. Environment International, 30, 953-971. DOI: 10.1016/j. envint.2004.02.001

[76] Franco, F, Benítez-Guerrero M, Gonzalez-Triviño I, Pérez-Recuerda R, Assiego C, Cifuentes-Melchor J, Pascual-Cosp J (2016), Low-cost aluminum and iron oxides supported on dioctahedral and trioctahedral smectites: a comparative study of the effectiveness on the heavy metal adsorption from water, Applied Clay. Science 119 321-332.

[77] Freundlich, H.M.F.,(1906). Over the adsorption in solution. Journal of Physical Chemistry, 57, pp.370-485.

[78] Fu, F. and Wang, Q. (2011). Removal of heavy metal ions from wastewaters: a review. Journal of Environmental Management,. 92(3): p. 407-418.

[79] Futalan, C.M.; Tsai, W.-C.; Lin, S.-S.; Hsien, K.-J.; Dalida, M.L.; Wan, M.-W. Copper, nickel and lead adsorption from aqueous solution using chitosan-immobilized on bentonite in a ternary system. Sustain. Environ. Res. 2012, 22, 345-355.

[80] Gandhi, M.R.; Viswanathanb, N.; Meenakshi, S. Preparation and application of alumina/chitosan biocomposite. Int. J. Biol. Macromol. 2010, 47, 146-154.Materials 2014, 7723.

[81] Gładysz-Płaska, A., Majdan M., Pikus, S. and Sternik, D. (2012). Simultaneous adsorption of chromium(VI) and phenol on natural red clay modified by HDTMA, Chemical. Engineering Journal. 179 140-150.

[82] Gomez-Serrano, V. (1998), Adsorption of mercury, cadmium and lead from aqueous solution on heat treated and sulphurized activated carbon. Journal of Water Research. 
[83] Goncharuk, V.V., Puzyrnaya, L.N., Pshinko, L.N., Bogolepov, A.A and Demchenko, V.Y (2010). The removal of heavy metals from aqueous solutions by montmorillonite modified with polyethylenimine, Journal of Water Chemistry and Technology. 32 67-72.

[84] Gonzalez, R.J., Videa, P.J.R. Rodriguez, E., Ramirez, S.L., and Gardeaorresdey J.L. (2005). Journal of Chemical Thermodynamics., 37, 343-347.

[85] Guadalupe, R., Reynel-Avila, H.E., Bonilla-Petriciolet, A. Cano-Rodríguez, I., Velasco-Santos, C. and Martínez-Hernández, A.L. (2008). Recycling poultry feathers for Pb removal from wastewater: kinetic and equilibrium studies.Proceedings of World Academy Of Science. Engineering And Technology Volume 30

[86] Gubernak, M., Zapala, W., and Kaczmarski, K. (2003). Amylbenzene adsorption equilibria on RP-18e chromatographic column, Acta Chromatographica, no. 13, pp. 38-59.

[87] Guerra, D.L. and Airoldi, C. (2008). Kinetics and modified clay thermodynamic from the Brazilian amazon region for lead removal, Journal of Hazardous Material. 159 412-419.

[88] Gupta, V. K., Kumar, R., Nayak, A., Saleh, T. A. and Barakat, M. A. (2013). Adsorptive removal of dyes from aqueous solution onto carbon nanotubes:a review, Adv. Colloid Interface Sci. 193: 24-34.

[89] Gupta, V.K., Rastogi, A., and Nayak A. (2010), Adsorption studies on the removal of hexavalent chromium from aqueous solution using a low cost fertilizer industry waste material. Journal of Colloid and Interface Science,. 342(1): p. 135-141.

[90] Haghdoost, S., Czene, S., Naslund, I., Skog, S., and Harms-Ringdahl, M (2005). Extracellular 8-oxo-dG as a sensitiveparameter for oxidative stress in vivo and in vitro. Free Radical. Resources., 39, 153-162.

[91] Hamdaouia, O. (2009). Removal of copper (II) from aqueous phase by Purolite C100-MB cation exchange resin in fixed bed columns: Modeling. Journal of hazardous materials. 161(2): p. 737-746.

[92] Hamdi, H., Benzarti, S., Manusadzianas, L., Aoyama, I. and Jedidid, N. (2007). Soil bioaugmentation and biostimulation effects on PAH dissipation and soil ecotoxicity under controlled conditions. Soil Biology and Biochemistry 39 1926-1935.

[93] Hamelink, J.L., Landrum, P.F., Harold, B.L. and William, B.H. (1994). Editors. Bioavailability: Physical, Chemical, and Biological Interactions. Boca Raton, FL: CRC Press Inc;

[94] Hayes, B.L. (2004) Recent Advances in Microwave Assisted Synthesis. Aldrichimica ACTA, Vol. 37, No. 2 .

[95] He, Z.L., Yang, X.E and Stoffella, P.J. (2005). Trace elements in agroecosystems and impacts on the environment. Journal of Trace Element in Medicinal Biology. (PubMed) 19 (2-3):125-140.

[96] Heineck, K.S., ConsolI, N.C., Cruz, R.C. and Knop A. (2007). Encapsulamento de um solo contamina- do por óleo diesel. Revista Geotecnia 110 3-17.

[97] Heiri, O., Lotter, A., and Lemcke, G. (2001). Loss on ignition as a method for estimating organic and carbonate content in Journal of Paleolimnology, 25: 101-110.

[98] Hesas, R.H., Arami-Niya, A., Daud, W.M.A.W. and Sahu, J.N. (2013) Preparation and characterization of activated carbon from apple waste by microwave-assisted phosphoric acid activation: Application in methylene blue adsorption, Bioresources 8(2), 2950-2966.

[99] Higarashi, M.M.(1999).Processos oxidativos avançados aplicados à remediação de solos brasileiroscontaminadoscompesticidas.PhDthesis.UniversidadeEstadualdeCampi-nas.

[100]Hongo,T.,Yoshino, S., Yamazaki A., Yamasaki, A. \& Satokawa, S. (2012). Mechano-chemical treatment of vermiculite in vibration milling and its effect on lead(II) adsorption ability, Applied Clay Science 70 74-78.

[101]Ionescu, C., Hoeck, V., and Simon, V. (2011). Effect of the temperature and the heating time on the composite of an illite-rich clay:anXRPDstudy, Stud. Universt. Babes-Bolyai Phys. 5670.

[102]Ismadji, F.E. Soetaredjo, A. and Ayucitra, A. (2015). Clay Materials for Environmental Remediation, in: Springer Briefs in Green Chemistry for Sustainability, <http://dx.doi.org/10.1007/978-3-31916712-1_1>.16712-1_1>.

[103]Itodo, A.U., Abdulrahman, F.W., Hassan, L.G., Maigandi, S.A. and Itodo, H.U (2010) Physicochemical parameters of Adsorbents from locally sorted $\mathrm{H} 3 \mathrm{PO} 4$ and $\mathrm{ZnCl} 2$ modified Agricultural wastes. New York Science Journal 3(5).

[104]Jaiswal, A., Banerjee, S., Mani, R. and Chattopadhyaya, M.C. (2013). "Synthesis, characterization and application of goethite mineral as an adsorbent," Journal of Environmental Chemical Engineering, vol. 1, no. 3, pp. 281-289.

[105]Jasperse, B.H. and Ryan, C.R. (1992), "Stabilization and Fixation Using Soil Mixing," in Proceedings of the ASCE Specialty Conference on Grouting, Soil Improvement, and Geosynthetics, ASCE Publications, Reston, VA. 
[106]Ji, M., Su, X., Zhao Y., Qi, W., Wang, Y., Chen, G. and Zhang, Z. (2015). Effective adsorption of Cr(VI) on mesoporous Fe-functionalized Akadama clay: optimization, selectivity, and mechanism, Applied Surface Science 344 128-136.

[107]Jiang, M.Q, Wang, Q.P, Jin, X.Y, and Chen, Z.L. (2009).Removal of Pb (II) from aqueous solution using modified and unmodified kaolinite clay. Journal of Hazardous Material., 170, 332-339.

[108]Joseph, S. H., Wong, R., Hicks R. E. and Probstein, R. F. (1997). J. Hazard. Mater. 55(1-3) 61.

[109]Kabata- Pendi. (2001). A 3rd, editor. Trace Elements in Soils and Plants. Boca Raton, FL: CRC Press

[110]Karaa, S., Aydinera, C., Demirbasb, E., Kobyaa, M., and Dizge, N. (2007). Modeling the effects of adsorbent dose and particle size on the adsorption of reactive textile dyes by fly ash. Science direct Desalination. 2: 282-293.

[111]Khan, T.A. and Singh, V.V. (2010). Removal of cadmium (II), lead (II), and chromium (VI) ions from aqueous solution using clay, Toxicology and Environmental Chemistry. 92 1435-1446.

[112]Kinniburgh, D.G., (1986). General purpose adsorption isotherms. Environmental Science and Technology, 20 (9), pp.895-904. 2.

[113]Kloprogge, J.T., Evans, R., Hickey, L. and Frost, R.L. (2002) Characterisation and Al-pillaring of smectites from Miles, Queensland (Australia). Applied Clay Science., 20, 157-163.

[114]Kounou, G.N., Nsami, J.N., Belibi, D.P.B., Kouotou, D., Tagne, G.M., Dina-Joh, D.D. and Mbadcam, K. (2015). Adsorption of Zinc(II) ions from aqueous solution onto kaoliniten and metakaolinite, Der Pharma Chem. 7 51-58.

[115]Krishna, B and Susmita, G. (2006). Adsorption of Fe (III) from water by natural and acidactivated clays: Studies on equilibrium isotherm, kinetics and thermodynamics of interactions, Colloid Surface Advancement 12:185-204

[116] Ku, Y. and Jung, I.L. (2001). Photocatalytic reduction of $\mathrm{Cr}$ (VI) in aqueous solutions by UV irradiation with the presence of titanium dioxide. Water Research, 35(1): p. 135-142.

[117]Kumar A.S.K., Kalidhasan S., Rajesh, V, and Rajesh, N. (2012). A meticulous study on the adsorption of mercury as tetrachloromercurate(II) anion with trioctylamine modified sodium montmorillonite and its application to a coal fly ash sample, Industrial Engineering and Chemical Resources. 51 11312-11327.

[118]Kumara, P. S., Ramalingamb, S., Kiruphac, S. D., Murugesanc, A. Vidhyadevic, T. and Sivanesan, S. (2011). "Adsorption behavior of nickel (II) onto cashew nut shell: Equilibrium, thermodynamics, kinetics, mechanism and process design," Chemical Engineering Journal., vol. 167, pp. 122-131,

[119]Kurniawan, T.A., (2006). Physico-chemical treatment techniques for wastewater laden with heavy metals. Chemical engineering journal,. 118(1): p. 83-98.

[120]Lagergren, S. (1898). Zur theorie der sogenannten adsorption gelöster stoffe (About the theory of so-called adsorption of soluble substances). Kungliga Svenska Vetenskapsakademiens. Handlingar, 24 (4), pp.1-39.

[121]Landoulsi O, Megriche A, Calvet R, Espitalier F, Ferreira JMF, Mgaidi A Ombaka 431 (2013). Effect of heating and acid activation on the structure and surface properties of a kaolinite-illiteSmectite clay mixture. Mineral Process Journal. 6:13-20.

[122]Langmuir, I. (1918)._The adsorption of gases on plane surfaces of glass, mica and platinum “. - Journal of America Chemical Society. 40, 1362-1403.

[123]Li, Z.., Yu, J. W. and Neretnieks, I. (1996). Journal of Contaminants and Hydrology. 22 241-253.

[124]Lidstrom P., Tierney J., Wathey B. and Westman J. (2001). Microwave assisted organic synthesis: a review, Tetrahedron, 57, 9225-9283.

[125]Lim Xiaozhi (2016) Grinding chemical together in an effort to be greener The New York Times. ISSN $0362-4331$

[126]Litvak, P., Slavkovich, V., Liu, X., Popovac, D., Preteni, E., Capuni-Paracka, S., Hadzialjevic, S., Lekic, V., Lolacono, N., Kline, J. and Graziano, J. (1998). Hyperproduction of erythropoietin in nonanemic leadexposed children. Environmental Health Perspective. (PMC free article PubMed) 106 (6):361-364.

[127]Liu, Y., Li, H., -H, X., and Zhu. (2010). Competitive adsorption of $\mathrm{Ag}^{+}, \mathrm{Pb}^{2+}, \mathrm{Ni}^{2+}$ and $\mathrm{Cd}^{2+}$ ions on vermiculite, Separation Science Technology. 45 277-287.

[128]López-Maldonado, E (2014) Coagulation-flocculation mechanisms in waste waterm treatment plants through zeta potential measurements. Journal of hazardous materials. 279: p. 110.

[129]Ma, L., Chen, Q., Zhu, J., Xi, J., He, H., Zhu, R., Tao, Q, and Ayoko, Q.A. (2016). Adsorption of phen ol and $\mathrm{Cu}$ (II) onto cationic and zwitterionic surfactant modified montmorillonite in single and binary systems, Chemical Engineering Journal. 283 880-888.

[130]Madejova (2003). FT-IR techniques in clay mineral structures: Review. Journal of Vibrational Spectroscopy 31(1):1-10. 
[131]Makeswari, M. and Santhi, T. (2013). Optimization of Preparation of Activated Carbon from Ricinus communis Leaves by Microwave-Assisted Zinc Chloride Chemical Activation: Competitive Adsorption of $\mathrm{Ni}^{2+}$ Ions from Aqueous Solution, Hindawi Publishing Corporation Journal of Chemistry Volume Article ID 314790.

[132]Manahan, S.E. (2001). Editor. Introduction to Chemistry: Fundaments of Environmental Chemistry. Boca Raton.

[133]Mattos, I.L., Shiraishi, K.A., Braz, A.D. and Fernandes, J.R. (2003) Peróxido de hidrogênio: importância e determinação. Química Nova 26(3) 273-380.

[134]Mbaye, A., Diop, C. A.., MieheBrendle,K Jocelyne, S. F and Maury.T (2014) Characterization of natural and chemically modified kaolinite from Mako (Senegal) to remove lead from aqueous solutions. Clay Minerals, 49 :527-539.

[135]Means, J.L. and Hinchee, R.E. (1994), Emerging Technology for Bioremediation of Metals, Lewis Publishers, Boca Raton, FL.

[136]Megharaj, M., Ramakrishnan, B., Venkateswarlu, K., Sethunathan, N. and Naidu, R. (2011). Bioremediation approaches for organic pollutants: a critical perspective. Environmental International 37 1362-1375.

[137]Miller, C.M., Valentine, R.L., Roehl, M.E. and Alvarez, P.J.J. (1996) Chemical and microbiological assessment of pendimethalin-contaminated soil after treatment with fenton's reagent. Water Research 20(11) 2579-2586.

[138]Miranda-Trevino, J. C. and Coles, C. A. (2003). Kaolinite properties, structure and influence of metal retention on $\mathrm{pH}$, Appl. Clay Sci. 23: 133-139.

[139]Miranda-Trevino, J.C. and Coles, C.A. (2003). Kaolinite properties, structure and influence of metal retention on pH, Applied Clay Science. 23 133-139.

[140]Mitchel J.K, Soga K. (2005). Fundamentals of Soil Behavior,., Wiley Press. third ed

[141]Mohammadi, B. and Pironneau, O. (2004). Shape optimization in fluid mechanics. Annual. Review of Fluid Mechanics. 36: p. 255-279.

[142]Mohan, S. and Karthikeyan. J. (1997). Removal of lignin and tannin color from aqueous solution by adsorption on to activated carbon solution by adsorption on to activated charcoal", Environmental Pollution. 97, pp.183-187

[143]Mohan, S.V., Kisa, T, Ohkuma, T., Kanaly R.A, and Shimizy, Y. (2006). Bioremediation technologies for treatment of PAH-contaminated soil soil and strategies to enhance process efficiency. Review of Environmental Science Biotechnology. 5 347-374.

[144]Mollah, M.Y.A (2001). Electrocoagulation (EC)—science and applications. Journal of hazardous materials,. 84(1): p. 29-41.

[145]Morton, W.E, and Dunnette, D.A. (1994). Health effects of environmental arsenic. In: Nriagu JO, editor. Arsenic in the Environment Part II: Human Health and Ecosystem Effects. New York: John Wiley \& Sons, Inc;. pp. 17-34.

[146]Moustafa, M. and Idris, G. (2003). Biological removal of heavy metals from wastewater. Alexandria Engineering Journal. 42(6): p. 767-771.

[147]Munnings, C. Badwal, S.P.S. and Fini, D. (2014) spontaneous stress induced oxidation of Ce ions in Gd dopped ceria at ceria at room temperature. Ionic. 20 (8)1117-1126.

[148]Murray, H. H (1999). Applied clay mineralogy today and tomorrow. Clay Mineral. 34:39-49.

[149]Muszkat, L., Bir, L. and Feigelson, L. (1995). Solar photocatalytic mineralization of pesticides in polluted waters. Journal of Photochemistry and Photobiology A: Chemistry8785-88.

[150]Na, P., Jia, X., Yuan, B., Li, Y., Na, J., Chen, Y. and Wang, L. (2010). Arsenic adsorption on Tipillared montmorillonite, Journal of Chemical Technology and Biotechnology. 85 708-714.

[151]Natalia, C. D, Patrícia, A.S. and Maria-Cristina, B. B. (2015).Charac-terization and Modification of a Clay Mineral Used in Adsorption Tests Journal of Minerals and Materials Characterization and Engineering. $3,277-288$

[152]National Research Council (NRC). Arsenic in Drinking Water. (1994) (PubMed). Update. On line at:http://www.nap.edu/ books/0309076293/html/

[153] Nriagu, J.O. (1989). A global assessment of natural sources of atmospheric trace metals. Nature. 338:47-49.

[154]O'Connell D.W., Birkinshaw C, O’Dwyer T.F (2008). Heavy metal adsorbents prepared from the modification of cellulose: areview,BioresourcesandTechnology.99 6709-6724.

[155]Obaroh, I.O., Abubakar, U., Haruna, M.A and Elinge, M.C, (2012). Evaluation of heavy metals concentrations of River Arungu. Journal of fisheries and aquatic science, 10: 581-586. 
[156]Oghbaei, M. and Mirzaee, O. (2010) Microwave versus conventional sintering: A review of fundamentals, advantages and applications, Journal of Alloys and Compounds 494, 175-189.

[157]Olayinka, K.O. and Alo, B.I. (2004). Studies on industrial pollution in Nigeria: the effect of textile effluents on the quality of ground water in some parts of Lagos. Nigerian Journal of Health and Biomedical Science., 3:44-50.

[158]Olu-Owolabi, B.I., Popoola, D.B. and Unuabonah, E.I. (2014). Removal of $\mathrm{Cu}^{2+}$ and $\mathrm{Cd}^{2+}$ from aqueous solution by Bentonite clay modified with binary mixture of geothite and humic acid, Water, Air and Soil Pollution. 211 459-474.

[159]Omar, W. and Al-Itawi, H. (20011). Removal of $\mathrm{Pb}^{2+}$ ions from aqueous solutions by adsorption on kaolinite clay, American Journal of Applied Science. 4 502-507.

[160]Opeolu, B. O. and Fatoki, O. S. (2012). Dynamics of zinc sorption from aqueous matrices using plantain (Musa sp.) peel biomass, African Journal of Biotechnology Vol. 11(68) pp. 13194-13201

[161]Osu, C . I. and Odoemelam,1.S.A., Studies on Adsorbent Dosage, Particle Sizes and pH Constraints on Biosorption of $\mathrm{Pb}(\mathrm{II})$ and $\mathrm{Cd}(\mathrm{II})$ Ions from Aqueous Solution Using Modified and Unmodified Crasstrotrea Gasar (Bivalve) Biomass. International achaive of applied science and technology India. ISSN 0976- 4828

[162] Otitoloju, A.A., Ajikobi, D.O. and Egonmwan R.I. (2009). Histopathology and Bioaccumulation of Heavy Metals $(\mathrm{Cu} \& \mathrm{~Pb})$ in the Giant land snail, Archachatina marginata (Swainson). The Open Environmental Pollution and Toxicology Journal 1 79-88.

[163]Ozdemir, G. and Yapar, S. (2009). Adsorption and desorption behavior of copper ions on Na-montmorillonite: effect of rhamnolipids and pH, Journal of Hazardous Material. 166 1307-1313;

[164]Parrish, Z.D., Banks, M.K. and Schwab, A.P. (2004). Effectiveness of Phytoremediation as a Secondary Treatment for Polycyclic Aromatic Hydrocarbons (PAHs) in Composted Soil. International Journal of Phytoremediation 6(2) 119-137.

[165]Paul, I. (1998) Re-use of coconut residues as activated carbon for domestic water purification. MSc. Thesis, Faculty of Humboldt state university, 66-70

[166]Pedrazzoli, C.D. (2004). Remediação eletrocinética de chumbo em resíduos industriais. PhD thesis. Removal with enhanced Process Universidade Federal do Paraná.

[167]Pergher, S.B.C., Corma, A., and Fornes, V. (1999) Materiales laminares pilareados: Preparación propiedades. Quim. Nova, 22, 693-709. CrossRef Materials, 10, 7058 of 9

[168]Petit, S., Decarreau, A. Mosser, C., Ehret, G. \&Grauby, O. (1995).Hydrothermal synthesis (250 $\left.{ }^{\circ} \mathrm{C}\right)$ of copper substituted kaolinites. Clay Minerals, 43, 482-494.

[169]Petrov, S. and Nenov, V. (2004). Removal andrecovery of copper from wastewater by a complexationultrafiltration process. Desalination,. 162: p. 201-209.

[170]Pizarro, A.H., Molina, C.B., Rodriguez, J.J. and Epron, F. (2015). Catalytic reduction of nitrate and nitrite with monoand bimetallic catalysts supported on pillared clays. J. Environ. Chem. Eng. (CrossRef), 3, 2777-2785.

[171]Pollard, S.J.T, Smith, R., Weeks, J.M. and Nathanail, C.P. (2006). Assessing significant harm to terrestrial ecosystems from contaminated land. Soil Use and Management 21 527-540.

[172]Pollard, S.J.T., Smith, R., Weeks, J.M. and Nathanail, C.P. (2006). Assessing significant harm to terrestrial ecosystems from contaminated land. Soil Use and Management ;21 527-540.

[173]Qin, J.M., Ping, W.Q., Ying, J.X, and Liang, C.Z. (2009). Removal of Pb (II) from aqueous solution using modified and unmodified kaolinite clay, Journal of Hazardous Material. 170 332-339.

[174]Ramachandra, T.V, SubashChandran, M.D, Joshi, N.V, Rajinikanth, R and Raushan, K. (2012).Water , soil and sediment characterization: Sharavathiriver basin, Western Gaths, ENVIS Technical report : 21, Energy and Wetlands Research Group, Center for Ecological Sciences, India Institute of Science, Bangalore 560012.

[175]Rao, R. A. K., Ikram, S. and Uddin, M. K. (2014). Removal of Cd (II) from aqueous solution by exploring the biosorption characteristics of gaozaban (Onosma bracteatum), J. Environ. Chem. Eng. 2: 1155-1164.

[176]Rao, R. A. K., Ikram, S. and Uddin, M. K. (2015). Removal of Cr (VI) from aqueous solution on seeds of Artimisia absinthium (novel plant material), Desalin. Water Treat. 54 3358-3371.

[177]Rao, R.A.K. and Kashifuddin M. (2012). Adsorption studies of Cd (II) on ball clay: comparison with other natural clays, Arab. J. Chem., http://dx.doi.org/10.1016/j.arabjc.2012.01.010.

[178]Rattanaphani, S., Chairat, M., Bremner, J. and V. Rattanaphani, (2007). Dyes and Pigment., $72,88$. 
[179]Rether, A. and Schuster, M. (2003). Selective separation and recovery of heavy metal ions using water-soluble N-benzoylthiourea modified PAMAM polymers. Reactive and Functional Polymers. 57(1): p. 13-21.

[180]Ross, C.S. (1999). The mineralogy of clays, in: Transactions of the 1st International Congress of Soil Science, Washington, D.C.; 4, pp. 555-561.

[181]Rousselot, P., Laboume, S., Marolleau, J.P, Larghero, T., Noguera, M.L, Brouet, J.C and Fermand JP. (1999). Arsenic trioxide and melarsoprol induce apoptosis in plasma cell lines and in plasma cells from myeloma patients. Cancer Res. (PubMed) 59:1041-1048.

[182]Saikia, N.J., Bharali, D.J., Sengupta, P., Bordoloi D., Goswamee, R.L., Saskia, P.C. and Borthakur P.C. (2003). Characterization, beneficiation and utilization of a kaolinite clay from Assam, India. Applied Clay Science, 24, 93y103.

[183]Sanusi, K.A., Umar B.A., \& San, I.M. (2016). Evaluation of the Application of Carica papaya Seed Modified Feldspar Clay for Adsorption of $\mathrm{Pb}^{+2}$ and $\mathrm{Cu}^{+2}$ in Aqueous Media: Equilibrium and Thermodynamic studies. Journal of Environmental and Analytical Toxicology http://dx.doi.org/10.4172/2161-0525.1000351

[184]Sari, A. and Tuzen, M. (2013). Adsorption of silver from aqueous solution onto raw vermiculite and manganese oxide-modified vermiculite. Microporous Mesoporous Mater. 170 155-163.

[185]Schnoor, J.L. (1997). Phytoremediation, TE-97-01, Ground-Water Remediation Technologies. Analysis Center, Pittsburgh, PA.

[186]Schoonheydt, R.A. and Jacobs, K.Y. (2001). Clays: From Two to Three Dimensions. In Studies in Surface Science and Catalysis; Elsevier Science B.V.: Amsterdam, The Netherlands; pp. 299-343.

[187]Senthil, K, Vincent, C., Kirthika, K., and Sathish, K.K (2010). Kinetics and equilibrium studies of $\mathrm{pb}^{2+}$ ion removal from aqueous solutions by use of nano-silversol-coated activated carbon. Brazilian Journal of Chemical Engineering. P. ISSN 0104-6632

[188]Shallari, S., Schwartz, C., Hasko, A, and Morel, J.L. (1998). Heavy metals in soils and plants of serpentine and industrial sites of Albania. Science Total and Environment. (PubMed) ;19209:133-142.

[189]Sharma, A.K. (2009). Experimental study on $75 \mathrm{~kW}$ downdraft (biomass) gasifier system. Renewable Energy. 34(7): p. 1726-1733.

[190]Sharma, Y.C. (2008). Thermodynamics of removal of cadmium by adsorption on an indigenous clay, Chemical Engineering Journal. 145 64-68.

[191]Shen, B., Chen, J. and Yue, S. (2015). Removal of elemental mercury by titanium pillared clay impregnated with potassium iodine. Microporous and Mesoporous Mater. $203216-223$.

[192]Shim, H.Y (2014) Application of Electrocoagulation and Electrolysis on the Precipitation of Heavy Metals and Particulate Solids in Washwater from the Soil Washing. Journal of Agricultural Chemistry and Environment, 3(04): p. 130.

[193] Shively, W., Bishop, P., Gress, D., and Brown, T. (1986), Leaching Tests of Heavy Metals Stabilized with Portland Cement, J. WPCF, 38: 234-241.

[194]Singh, P. (2004). Enhancement of metal bioremediation by use of microbial surfactants. Bioche-mical and Biophysical Research Communications 319 291-297.

[195]Smith, L.A., Means, J.L., Chen, A., Alleman, B., Chapman, C.C., Tixier, J.S., Brauning, S.E., Gavaskar, A.R., and Royer, M.D. (1995), Remedial Options for Metals-Contaminated Sites. Lewis Publishers, Boca Raton, FL.

[196]Souza, T.S., De-Angelis, D.F. and Fontanetti, C.S. Histological and histochemical analysis of the fat body of Rhinocricus padbergi (Diplopoda) exposed to contaminated industrial soil. Water, Air and Soil Pollution 2011; 221 235-244.

[197]Stanley. M.W (2012). Intercalation chemistry. Elsevier. ISBN 978-0-323-14040—9

[198]Strater, E., Westbeld, A. and Klemm, O. (2010). Pollution in coastal fog at Alto Patache, Northern Chile. Environ Sci Pollut Res Int. Epub ahead of print. PubMed

[199]Sumathi, K.M., Mahimairaja, S. and Naidu, R. (2005). Use, of low-cost biological wastes and vermiculite for removal of chromium from tannery effluent. Bioresource Technology 96, 309-316. DOI: 10.1016/j.biortech.2004.04.015

[200]Swedlund, P.J., Webster, J.G. and Miskelly, G.M. (2009). Goethite adsorption of Cu (II), Pb (II), Cd (II), and $\mathrm{Zn}$ (II) in the presence of sulfate: properties of the ternary complex, Geochim. Cosmochim. Acta 73 $1548-1562$.

[201]Tang,D.S.(2007).Extraction \& purification of solanesol from tobacco:(I). Extraction and silica gel column chromatography separation of solanesol. Separation and purification technology. 56(3): p. 291-295. 
[202]Tchobanoglous, G., Hilary, T. and Vigil, S. (1993). In paul, water quality, 1st Ed. Addison Wesleyn publishing. Readings, Massachusetts.160-179.

[203]Teixeira, S.C.G., Ziolli, R.L., Marques, M.R.C. and Pérez, D.V. (2011). Study of pyrene adsorption on two brazilian soils, Water Air Soil Pollut. 219 297-301.

[204]Temkin, M.I. and Pyzhev, V. (1940). Kinetics of ammonia synthesis on promoted iron catalyst, Acta Phys. Chim. USSR 12, 327-356.

[205]Theng, B.K.G, (1979). Formation and Properties of Clay-Polymer Complexes. Developments in Soil Science, Elsevier Press, vol. 9 p. 359.

[206]Theocharis, C.R., Jacob, K.J. and Gray, A.C. (1988). Enhancement of lewis acidity in layer aluminosilicates. Journal of Chemical Society. Faraday Trans 84: 1509-1516

[207]Thorpe, V.A. (1973). Collaborative study of the cation exchange capacity of peat minerals. Journal of the AOAC, 56: 154-156

[208]Thostenson, E.T. and Chou, T.W. (1999) Microwave processing: Fundamentals and application, Composites Part A: Journal of colloid and Interface Science 286, 90-100.

[209]Tien, D.P., Hoang, H.N., Ngoc, V.N., Thanh, T.V., Thi, N.M., Pham, T.H., Yen, D., Manh, H.N and Thi M.V.N (2017) Adsorptive Removal of Copper by Using Surfactant Modified Laterite Soil. Hindawi Journal of Chemistry https://doi.org/10.1155/2017/1986071

[210]Tripathy, T. and De, B.R. (2006). Flocculation: a new way to treat the waste water. Water. 52. 116-122

[211]Trivunac, K. and Stevanovic, S. (2006). Removal of heavy metal ions from water by complexation assisted ultrafiltration. Chemosphere, 64(3): p. 486-491.

[212]Tuin, B.J.W., Senden, M.M.G., and Tels, M (1987) Extractive Cleaning of Heavy Metal Contaminated Clay Soils, from Environmental Technology: Proceedings of the Second European Conference on Environmental Technology, Nijhoff Publisher, Dordrecht.

[213]United State Environmental Protection Agency, (1996b). Report: Recent Developments for In Situ Treatment of Metals contaminated Soils. U.S. Environmental Protection Agency, Office of Solid Waste and Emergency Response, draft.

[214]United State Environmental Protection Agency, (1997). Engineering Bulletin: Technology Alternatives for the Remediation of Soils Contaminated with Arsenic, Cadmium, Chromium, Mercury, and Lead. USEPA - Office of Emergency and Remedial Re - sponse.

[215]United State Environmental Protection Agency, (2002). - FRTR (Federal Remediation Technologies Roundtable): Abstracts of Remediation Case Studies and Technology Assessment-fact sheet. USEPA p. 6.

[216]Unuabonah, E.I. and Adebowale, K.O. (2009). Optimization of kinetic data for two-stage batch adsorption of $\mathrm{Pb}$ (II) ions onto tripolyphosphate-modified kaolinite clay. Journal of Chemical Technology and Biotechnology. 84 1726-1735.

[217]Unuabonah,E.I.,Adebowale,K.O.,Olu-Owolabi,B.I.,Yang,L.Z.andKong, L.X.(2008). Adsorption of Pb(II) and $\mathrm{Cd}(\mathrm{II})$ from aqueous solutions onto sodium tetraborate-modified Kaolinite clay:Equilibrium and thermodynamic studies. Hydrometallurgy,

[218]USC Mineralogy Geol 215a (Anderson). Clay minerals: soils to engineering technology to cat litter. (Available: https://web.viu.ca/earlw/geo312/usc-anderson-clays.pdf).

[219]Valaskova, M., Martynkova, G.S. and Raaen, A.M (2012). Vermiculite: Structural Properties and Examples of the Use of Clay Minerals in Nature - Their Characterization, Modification and Application. Intech Publisher Press, pp. 209-238.

[220]Van der-Marel H.W. and Beutelspacher, S. (1976). Atlas of Infrared Spectroscopy of Clay Minerals and their Admixtures, Elsevier, Amsterdam . 397.

[221]Van, B.T.C., Verweij, R.A., Wedzinga, S.A. and Van, G.C.A.M. (1996). Polycyclic aromatic hydrocarbons in earthworms and isopods from contaminated forest soils. Chemosphere 32(2) 315-341.

[222]Veli, S, and Alyuz, B. (2007). Adsorption of copper and zinc from aqueous solutions by using natural clay, Journal of Hazardous Material. 149 226-233.

[223]Venkateswarlu, S., Rao, S.Y., Balaji, T., Prathima, B. and Jyothi, N.V.V. (2013). Biogenic synthesis of $\mathrm{Fe} 3 \mathrm{O} 4$ magnetic nanoparticles using plantain peel extract, Elsevier Materials Letters 100 241-244.

[224]Verkleji, J.A.S. (1993). In: The effects of heavy metals stress on higher plants and their use as biomonitors In Plant as Bioindicators: Indicators of Heavy Metals in the Terrestrial Environment. Markert B, editor. New York: VCH. pp. 415-424.

[225]Vigneswaran, R. (2004). Cerebral palsy and placental infection: a case-cohort study. BMC pregnancy and childbirth. 4(1): p. 1. 
[226]Voudrias, E., Fytianos, F. and Bozani, E. (2002). : Sorption Description isotherms of Dyes from aqueous solutions and Waste Waters with Different Sorbent materials, Global Nest, The International Journal. $4(1), 75-83$

[227]Wang, X.; Wang, A. Equilibrium isotherm and mechanism studies of $\mathrm{Pb}(\mathrm{II})$ and $\mathrm{Cd}(\mathrm{II})$ ions onto hydrogel composite based on vermiculite. Desalin. Water Treat. 2012, 48, 38-49.

[228]Wang, X.; Zheng, Y.; Wang, A. Fast removal of copper ions from aqueous solution by chitosan-g-poly(acrylic acid)/attapulgite composites. J. Hazard. Mater. 2009, 168, 970-977.

[229]WHO/FAO/IAEA. World Health Organization. (1996). Trace Elements in Human Nutrition and Health. Switzerland: Geneva.

[230]Williams RB, Environmental US (2005). Bentolite, kaolin, and selected clay minerals: Environmental health criteria. 15:1-196

[231]Williford, C., Bricka, R.M. and Iskandar, I. (2000). Physical separation of metal-contaminated soils: CRC Press LLC, Boca Raton.

[232]Wilson M (1999).Formation of clay minerals in soil: past, present and future perspective. Clay Mineral. 34:7-25.

[233]Wilson, M.J. (1994). Clay Mineralogy: Spectroscopic and Chemical Determinative Methods,. Chapman and Hall, London, UK18-60.

[234]World Health Organization- WHO (2004). Guidelines for Drinking Water Quality (3rd Edition) Volume 1, Recommendation, Geneva, Switzerland.

[235]Yadoji, P., Peelamedu, R., Agrawal, D. and Roy, R. (2003) Microwave sintering of Ni-Zn ferrites: Comparison with conventional sintering. Materials Science and Engineering: B 98, 269-278.

[236] Yalcin, B., Acar, D. and Daniel, E. (1995). American Society of Civil Engineers, New York, NY, USA, p. 1564-1575.

[237]Yeung, A. T., Chung, M., Corapcioglu, M. Y. and Stallard, W. M. (2000). In Geoenvironment: Characterization, Containment, Remediation, and Performance in Environmental Geotechnics.Geotechnical Special Publication (GSP) No. 46, Vol. 2,

[238]Yu,R.,Wang,S.,Wang,D.,Ke, J., Xing, X., Kumada, N.\&Kinomura, N. (2008). Removal of Cd ${ }^{2+}$ from aqueous solution with carbon modified aluminum-pillaredmmontmorillonite, Catal. Today 139 135-139.

[239]Zacaroni, L.M,. Magriotis, Z.M., Cardoso, M.G., Santiago, W.D., Mendonça, Jo-G., Vieira, S.S. and Nelson, D.L. (2015). Natural clay and commercial activated charcoal: properties and application for the removal of copper from cachaça, Food Control 47 536-544.

[240]Zhu, J., Cozzolino, V., Pigna, M., Huang, Q., Caporale, A.G., and Violante, A. (2011). Sorption of Cu, Pb and $\mathrm{Cr}$ on Na-montmorillonite: competition and effect of major elements. Chemosphere 84 484-489.

[241]Zouraibi, M., Ammuri, A., Khadija, Z. and Saidi M. (2016) Adsorption of Cu (II) onto natural clay: Equilibrium and thermodynamic studies Journal of Material and Environmental Science. 7 (2) 566-570

Citation: Adekeye Damilola Kayode, et.al, "Clay Soil Modification Techniques for the Adsorption of Heavy Metals in Aqueous Medium: A Review”. International Journal of Advanced Research in Chemical Science (IJARCS), 6(6), pp. 14-31, DOI:http://dx.doi.org/10.20431/2349-0403.0606003

Copyright: (C) 2019 Authors. This is an open-access article distributed under the terms of the Creative Commons Attribution License, which permits unrestricted use, distribution, and reproduction in any medium, provided the original author and source are credited. 